\title{
Statistical modelling of the surface mass-balance variability of the Morteratsch glacier, Switzerland: strong control of early melting season meteorological conditions
}

\author{
HARRY ZEKOLLARI, ${ }^{1,2,3}$ PHILIPPE HUYBRECHTS ${ }^{1}$ \\ ${ }^{1}$ Earth System Science \& Department Geografie, Vrije Universiteit Brussel, Brussels, Belgium \\ ${ }^{2}$ Laboratory of Hydraulics, Hydrology and Glaciology (VAW), ETH Zürich, Zurich, Switzerland \\ ${ }^{3}$ Swiss Federal Institute for Forest, Snow and Landscape Research (WSL), Birmensdorf, Switzerland \\ Correspondence: Harry Zekollari <zharry@ethz.ch>
}

\begin{abstract}
In this study we analyse a 15-year long time series of surface mass-balance (SMB) measurements performed between 2001 and 2016 in the ablation zone of the Morteratsch glacier complex (Engadine, Switzerland). For a better understanding of the SMB variability and its causes, multiple linear regressions analyses are performed with temperature and precipitation series from nearby meteorological stations. Up to $85 \%$ of the observed SMB variance can be explained by the mean May-June-July temperature and the total precipitation from October to March. A new method is presented where the contribution of each month's individual temperature and precipitation to the SMB can be examined in a total sample of $2^{24}(16.8$ million) combinations. More than $90 \%$ of the observed SMB can be explained with particular combinations, in which the May-June-July temperature is the most recurrent, followed by October temperature. The role of precipitation is less pronounced, but autumn, winter and spring precipitation are always more important than summer precipitation. Our results indicate that the length of the ice ablation season is of larger importance than its intensity to explain year-toyear variations. The widely used June-July-August temperature index may not always be the best option to describe SMB variability through statistical correlation.
\end{abstract}

KEYWORDS: energy balance, glacier cover, glacier mass balance, glacier meteorology, glacier monitoring

\section{INTRODUCTION}

Mountain glaciers worldwide have retreated significantly in the past decades as a consequence of an increase in global temperature (Vaughan and others, 2013). This resulted in an important contribution to global sea-level rise (Church and others, 2013; Marzeion and others, 2017) and profoundly affects water supply, hydro-electricity production, natural hazards and tourism in mountainous regions (e.g. Werder and others, 2010; Farinotti and others, 2012; Vincent and others, 2012; Gilbert and others, 2015; Huss and Hock, 2015, 2018; Ragettli and others, 2016; Kääb and others, 2018). Many studies have highlighted these changes for glaciers in the Swiss Alps through a wide range of approaches, based on for instance geodetic methods, LIDAR measurements, Unmanned Aerial Vehicle (UAV) surveys and three-dimensional glacier evolution modelling (Jouvet and others, 2009; Gabbud and others, 2015, 2016; Zekollari and Huybrechts, 2015; Fischer and others, 2016; Sold and others, 2016; Gindraux and others, 2017; Rossini and others, 2018). These changes are largely driven by a strongly negative surface mass-balance $(\mathrm{SMB})$ trend (Huss and others, 2015; Zemp and others, 2015; Vincent and others, 2017), which has been modelled at a variety of horizontal scales and through models of varying complexity for glaciers in the European Alps (e.g. Klok and Oerlemans, 2002; Huss and others, 2008; Machguth and others, 2009; Nemec and others, 2009; Berthier and Vincent, 2012; Gabbi and others, 2014; Huss and Fischer, 2016; Réveillet and others, 2017). Process-based SMB models are powerful and very useful tools for many applications, but they rely on parameterisations, simplifications and assumptions that influence the relationship between the model input (meteorological data) and output (modelled SMB). In order to better quantify the link between meteorological data and $\mathrm{SMB}$, direct statistical methods therefore represent an attractive alternative. Furthermore, such statistical methods can be useful tools for cases where the necessary measurements needed to setup more sophisticated SMB models (e.g. albedo and radiation measurements) are not available.

The first studies that laid the foundation for multivariate statistical regression between SMB data and meteorological observations were performed at the end of the 1970s (Young, 1977; Martin, 1978; Tangborn, 1980). Since then, multivariate statistical regressions have been widely applied, under slightly varying forms, among others for glaciers in the Rocky Mountains and Coast Mountains (Western Canada) (Letréguilly, 1988), Svalbard (Lefauconnier and Hagen, 1990; Lefauconnier and others, 1999), Norway (e.g. Trachsel and Nesje, 2015) and in the European Alps (e.g. Chen and Funk, 1990; Vincent and Vallon, 1997; Torinesi and others, 2002). The majority of these studies highlight the importance of summer temperature and winter precipitation, which variables are typically used to describe the observed SMB trends.

Here we analyse a 15-year dataset of SMB measurements from the ablation zone of the Morteratsch glacier complex (Switzerland) and investigate the meteorological variables that best describe the interannual variability in SMB through multiple linear regression analysis (MLRA). Compared with previous studies, where the meteorological input mostly 
consists of adjacent clusters of months, we introduce a new method in which all possible monthly combinations are considered. Our main objective is to make use of this new method to describe the measured SMB variations through a statistical analysis that is as simple as possible, i.e. relying on a minimal number of predictor variables to describe as much of the SMB variability as possible.

\section{LOCATION, FIELDWORK AND DATA}

\subsection{Location and fieldwork}

The Morteratsch glacier complex is situated on the southern side of the European Alps (Engadine, SE Switzerland) and consists of two glaciers, the Morteratsch glacier (Vadret da Morteratsch) and the Pers glacier (Vadret Pers) (Fig. 1). Until 2015, Vadret Pers was the main tributary of the Vadret da Morteratsch (Zekollari and Huybrechts, 2015), but now both glaciers have disconnected and act as independent ice bodies. At present, the glacier complex covers an area of $\sim 16 \mathrm{~km}^{2}$ and has a volume of $\sim 1.1 \mathrm{~km}^{3}$ (Zekollari and others, 2013).

Since 2001 we measured the SMB on the glacier complex from an elaborate stake network emplaced in its ablation area and around the ELA. These measurements were performed at the very end of September/beginning of October, around the time of the first snowfall events that mark the end of the ablation season and the onset of the accumulation season. For some years, some additional ablation occurred in October, while for others the annual ice ablation already stopped at the time of measurements due to an earlier (September) snowfall event. The stake position was measured with high precision GPS systems, which were corrected with reference base stations until 2013 (see Zekollari and others, 2013). More recently Real Time Kinematic (RTK) GPS systems were used.

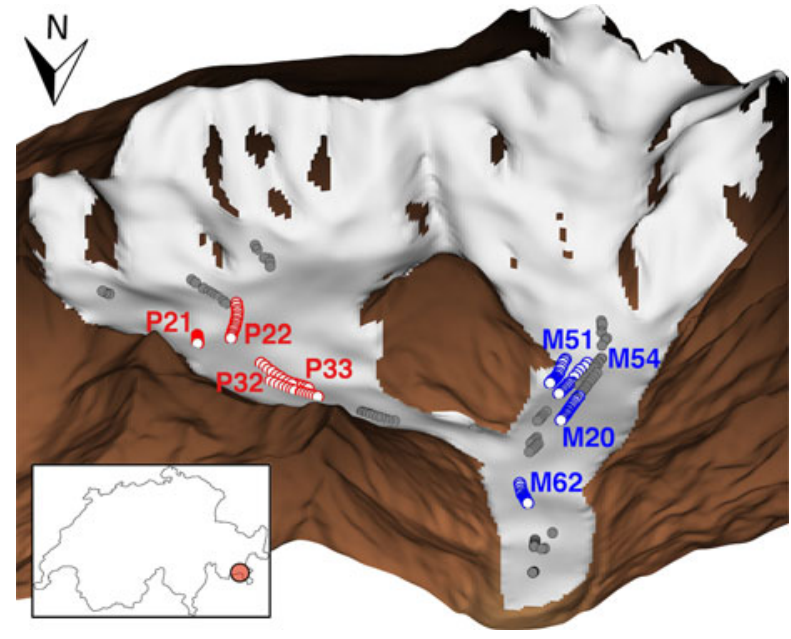

Fig. 1. Overview of the Morteratsch glacier complex and stakes for SMB measurements in the ablation area. The eight stakes used in the multiple linear regression analysis (MLRA) are shown in blue (Vadret da Morteratsch) and red (Vadret Pers), the other stakes are represented in light grey. The terminus is at $\sim 2100 \mathrm{~m}$ a.s.l., while the highest mountain peaks are $\sim 4000 \mathrm{~m}$. The SwissTopo Digital Elevation Model (DEM) used to produce this figure is from 2001 (i.e. start of the field campaign). Figure created with TopoZeko toolbox (Zekollari, 2017).

\subsection{Meteorological data}

For the analysis, data from two nearby MeteoSwiss stations are used, from a meteorological station in Samedan (1708 m a.s.l., $46^{\circ} 32^{\prime} \mathrm{N}, 9^{\circ} 53^{\prime} \mathrm{E}$ ) and from a station in Segl-Maria (1804 m a.s.l., $46^{\circ} 26^{\prime} \mathrm{N}, 9^{\circ} 46 \mathrm{E}^{\prime}$ ) (see Fig. 2a). The temperature signal is very similar for both stations $\left(R^{2}=0.99\right.$ for the period 2001-2016), but the station of Samedan shows a slightly higher seasonal contrast with lower winter temperatures (see Fig. 2a). This is a consequence of a stronger winter inversion in the valley at Samedan compared with Segl-Maria. Precipitation is higher at Segl-Maria: for the period covering the SMB measurements, the average annual precipitation at Segl-Maria is $932 \mathrm{~mm} \mathrm{a}{ }^{-1}$, while for Samedan it is $683 \mathrm{~mm} \mathrm{a}^{-1}$ (27\% lower). The higher precipitation in SeglMaria results from the fact that the precipitation mostly comes from the south over the Maloja pass and that the air dries up when advancing in the Engadine valley towards Samedan. Meteorological conditions at these stations are good indicators for conditions on the glacier, as revealed by measurements from an in situ meteorological station on the Morteratsch glacier (Klok and Oerlemans, 2002, 2004). Another nearby meteorological station is also available, at Piz Corvatsch $\left(46^{\circ} 25^{\prime} \mathrm{N}, 9^{\circ} 49^{\prime} \mathrm{E}\right)$, but due to its high elevation (3302 $\mathrm{m})$, this station is more representative for high mountain conditions and the free troposphere. The local valley meteorological conditions, which mostly affect the ablation area of the glacier due to the often-present temperature inversion, are therefore better represented by the Segl-Maria and Samedan stations. As we are interested in the interannual variability in meteorological parameters, which is very similar for SeglMaria and Samedan, we opt to use the average temperature and precipitation of both stations for the statistical correlations performed further below. Both stations are at a similar distance from the glacier: $12.2 \mathrm{~km}$ in a direct line from the glacier snout for the Samedan station and $13.4 \mathrm{~km}$ for the Segl-Maria station.

\subsection{Ablation measurements}

Over the 15-year period, a total of 232 annual mass-balance point measurements are available for the ablation area and around the Equilibrium Line Altitude (ELA) of the Morteratsch glacier complex (Fig. 3). These readings result from annual visits to the glacier, which occur at the very end of September - beginning of October, corresponding to a floating-date system that is very close to the fixed-date system (Cogley and others, 2011). Of the 232 readings, eight have a positive mass balance (up to $+0.6 \mathrm{~m}^{\text {ice }}$ eq $\mathrm{a}^{-1}$ ) (Fig. 3). A total of 128 readings were performed on Vadret da Morteratsch and 104 on Vadret Pers (see Fig. 1). These readings were obtained from 31 separate stakes (17 on Vadret da Morteratsch, 14 on Vadret Pers), of which 12 stakes have a series of at least 10 years and eight stakes cover the full 15-year period. The entire dataset is available as Supplementary material. For Vadret da Morteratsch, the elevation of the stakes ranges from the front ( 2030-2100 m a.s.l. over this period) to $\sim 2600 \mathrm{~m}$ a.s.l. (just underneath the icefall, the 'labyrinth'). Most of this range is covered with stakes, roughly at $100 \mathrm{~m}$ height intervals (see also Fig. 1). For Vadret Pers, two SMB observations were taken at the front ( $2450 \mathrm{~m}$ a.s.l.), but all other measurements are situated between 2600 and $3050 \mathrm{~m}$ a.s.I. ( the ELA). The SMB is significantly lower on Vadret Pers compared with Vadret da 

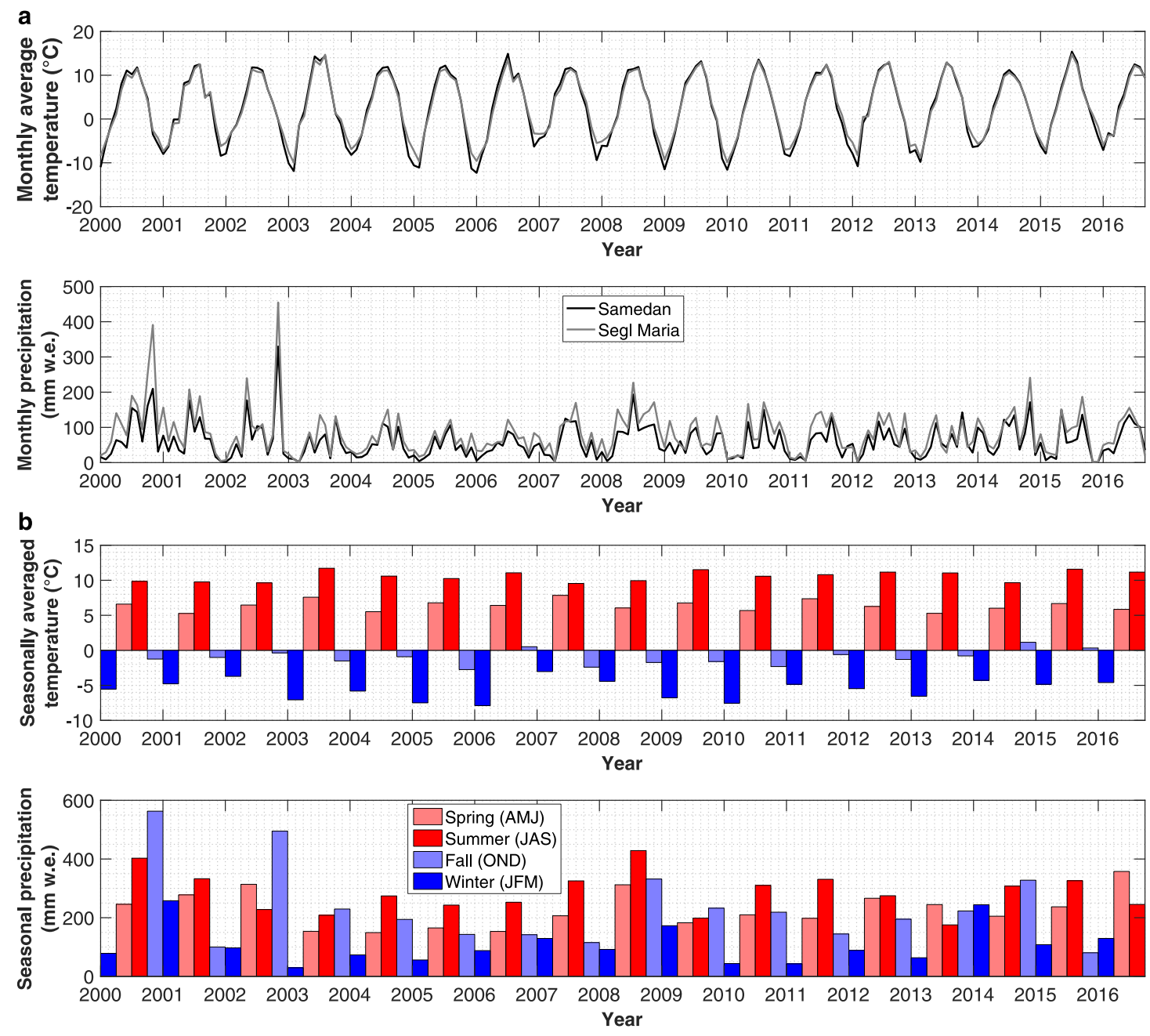

Fig. 2. (a) Mean monthly daily temperature and monthly precipitation for the MeteoSwiss meteorological stations of Segl-Maria and Samedan. (b) Mean seasonal mean daily temperature and seasonal precipitation averaged for the meteorological stations of Segl-Maria and Samedan.

Morteratsch (Fig. 3), which is likely related to the orientation and resulting daily insolation cycle for both glaciers. The ablation area of the Pers glacier is oriented towards the WNW (tongue)-NW (upper ablation area) and is more exposed to

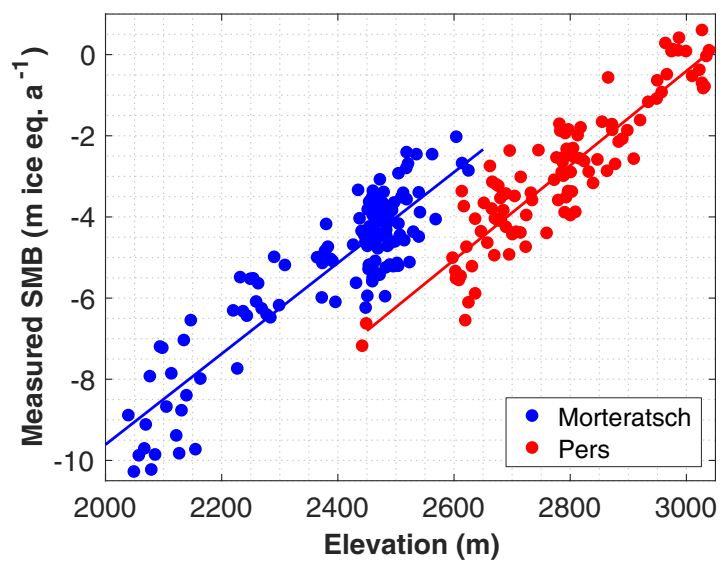

Fig. 3. Mean annual surface mass balance against elevation for the Pers and Morteratsch glacier for all 232-point measurements. The coloured lines represent the best linear fit for both glaciers individually (Eqns (1) and (2)). direct insolation than the Morteratsch glacier, which is exposed to the $\mathrm{N}$ and strongly shielded by the high mountain peaks (see also Fig. 1). A simple approach in which a best linear fit (i.e. linear regression) through all stakes is taken clearly illustrates the higher SMB for Morteratsch in the 2000-3000 m elevation range (ablation area):

$$
\begin{aligned}
\mathrm{SMB}_{\text {MORT }}= & 0.01119( \pm 0.00098) \text { ELEV } \\
& -31.98( \pm 2.36)\left(R^{2}=0.80\right), \\
\mathrm{SMB}_{\text {PERS }}= & 0.01164( \pm 0.00106) \mathrm{ELEV} \\
& -35.31( \pm 2.98)\left(R^{2}=0.82\right),
\end{aligned}
$$

where $\mathrm{SMB}_{\mathrm{MORT} / \mathrm{PERS}}$ is the annual measured $\mathrm{SMB}$ (in meter ice equivalent), ELEV is the stake elevation (in $\mathrm{m}$ a.s.l.) and the uncertainties correspond to the $95 \%$ confidence bounds. Based on this very simple approach, for the period 20012016, the average ELA for the Morteratsch glacier is expected to occur at $2859 \mathrm{~m}$, which is a slight underestimation compared with remote-sensing observations (Chan and others, 2009). This is likely related to the fact that the SMB-elevation gradient decreases towards the ELA. For the Pers glacier, the linear correlation suggests that the ELA for this period is at $3035 \mathrm{~m}$, which agrees very well with observations (see 
Fig. 3). The difference in ELA between both glaciers is typically of the order of $150 \mathrm{~m}$ for this period. Direct SMB measurements in the ablation area of the Morteratsch glacier are $\sim 2.1-2.5 \mathrm{~m}$ ice eq. $\mathrm{a}^{-1}$ higher than these measured on the Pers glacier at the same elevation. These are large differences in SMB and ELA given the close proximity of both glaciers.

\section{DATA HANDLING AND STATISTICAL BACKGROUND}

For the MLRA, 120 SMB measurements are considered, which correspond to the eight stakes that cover the whole observational period (i.e. the 15-year record). All eight stakes are in the ablation zone and are in debris-poor areas. Four of these stakes are located on Vadret da Morteratsch and four on Vadret Pers (see Fig. 1). Including SMB measurements from stakes that do not cover this entire period would introduce bias in the anomalies due to the gap in their data record. Since SMB data from the eight stakes covering the full period would be needed to solve these biases, this approach would not add information about total SMB variance.

The SMB stakes undergo elevation changes as time evolves due to their movement along with the glacier flow and due to changes in local ice thickness (Zekollari and others, 2014; Fischer and others, 2015). Over the 15-year period, the elevation change for the eight stakes ranges from $-115 \mathrm{~m}$ (P33) to $-44 \mathrm{~m}$ (P21). To account for this effect, all stakes are projected back to their initial elevation (in 2001) based on the SMB-elevation gradients found from the simple linear correlation (Eqns (1) and (2)). For the Pers glacier, this corresponds to $0.0116 \mathrm{~m}$ ice eq. $\mathrm{a}^{-1} \mathrm{~m}^{-1}$, while for the Morteratsch glacier, this is $0.0112 \mathrm{~m}$ ice eq. $\mathrm{a}^{-1} \mathrm{~m}^{-1}$. Corrections based on the annual values of the mass-balance gradient lead to almost identical results and do not significantly alter the results as the elevation change is relatively limited and the SMB-elevation gradient varies only little over time.

The individual stake measurements are shown in Figures $4 a, b$. The highest SMB is observed for the balance years 2003-2004, 2012-2013 and 2013-14, and lowest SMB for 2002-2003 and 2014-2015. The stakes have a consistent annual SMB signal. For these elevation change corrected $\mathrm{SMB}$ values, no significant trend is observed over the 15year period $\left(R^{2}=0.13, p\right.$-value $F$-test $\left.=0.185\right)$. The std dev. in SMB per stake over the entire period varies between 0.6 and $0.9 \mathrm{~m}$ ice eq. $\mathrm{a}^{-1}$ and is not correlated to elevation $\left(R^{2}=0.04\right)$ (Fig. $\left.4 \mathrm{C}\right)$. For the analysis, the elevation-corrected SMB measurements for each stake are converted to perturbations with respect to the 15-year stake mean. As shown on Figure 4d, the annual SMB perturbation is largely similar over the whole ablation area, for both glaciers taken together and for Vadret Pers and Vadret da Morteratsch separately. No link with elevation is observed. This is underscored by the very high correlation $\left(R^{2}=\right.$ 0.85-0.91) between the SMB perturbation of individual stakes and the mean perturbation over all stakes (Table 1 ). Exceptions are M51 and M62 with a somewhat lower $R^{2}$ of between 0.62 and 0.67 , where a few individual measurements (M51 in 2005-06 and 2015-16 and M62 in 2008-09 and 2012-13) cause a slight deviation from the mean perturbation. Despite this, the correlation between the perturbation of these individual stakes and the mean perturbation over all stakes is still very significant ( $p$-values of $2 \times 10^{-4}$ and $5 \times 10^{-4}$, respectively). Furthermore, no link between the meteorological data (temperature and precipitation) and annual SMB elevation gradient is found. The presence of a common SMB signal, which is independent from the location, is a prerequisite for our analyses and is in line with the time-space decomposition as proposed by Lliboutry (1974) and related studies (Meier and Tangborn, 1965; Kuhn, 1984; Rasmussen, 2004; Eckert and others, 2011).

The SMB perturbations over the eight stakes are averaged on an annual basis, and the same is done for the meteorological variables, which are averaged over the two meteorological stations. To assess the glacier's sensitivity to temperature and precipitation changes, which are measured in different units $\left({ }^{\circ} \mathrm{C}\right.$ and $\mathrm{mm}$ w.e., respectively), these values are standardised through a conversion to a z-score, which corresponds to the number of standard deviations that a value is separated from the mean value.

The correlation between SMB perturbation and meteorological data are tested with MLRA (e.g. Legendre and Legendre, 2012):

$$
y=a_{1} x_{1}+a_{2} x_{2}+\ldots+a_{n} x_{n}+b .
$$

Here $y$ is the dependent variable (also referred to as response variable; the $\mathrm{SMB}$ perturbation in this study), $a_{i}$ and $b$ are the regression coefficients and $x_{i}$ are the independent variables (also referred to as predictor variables; the $z$-score of the meteorological components in this study, i.e. temperature and precipitation). The monthly temperature and precipitation series used in our analyses have a very weak correlation $\left(R^{2}=0.17\right.$ when all months are considered, with the highest correlation in spring (MAM): $R^{2}=0.21$ and lowest correlation in winter (DJF): $R^{2}=$ 0.04). They can therefore be considered as being uncorrelated, which is a common approach for MLRAs performed on SMB series (e.g. Lefauconnier and others, 1999; Trachsel and Nesje, 2015). Due to the conversion of the meteorological data to a $z$-score, the regression coefficient $\left(a_{i}\right)$ of variables represents the climatic variability of this variable. Under this $z$-score approach, the standard regression coefficients for temperature and precipitation are directly comparable and, assuming both are entirely uncorrelated, indicate the relative importance of both for the SMB. Furthermore, the standardisation procedure leads to an intercept of the regression analysis $(b)$ that is equal to zero: i.e. under the mean 2001-2016 climatological conditions ( $z$-score of 0 for the independent variables), the mean 2001-2016 SMB is obtained (dependent variable is 0 ). For each MLRA the error degrees of freedom correspond to the difference between the total number of years (15 in this case) and the number of independent variables in the analysis.

The outcome of each MLRA is expressed as a $R^{2}$ value and a $p$-value for the $F$-test. The $R^{2}$ value corresponds to the fraction of the variability in the response variable that the model explains. The $F$-test tests for a significant linear regression relationship between the response variable and the predictor variables. The $p$-value of the $F$-test, also referred to as calculated probability, is the probability of obtaining a result (a linear correlation) equal to or more extreme than what is observed when the null hypothesis (no linear correlation) is true. The lower the $p$-value, the higher the confidence (lower significance level) at which the null hypothesis (no linear correlation) can be rejected. 

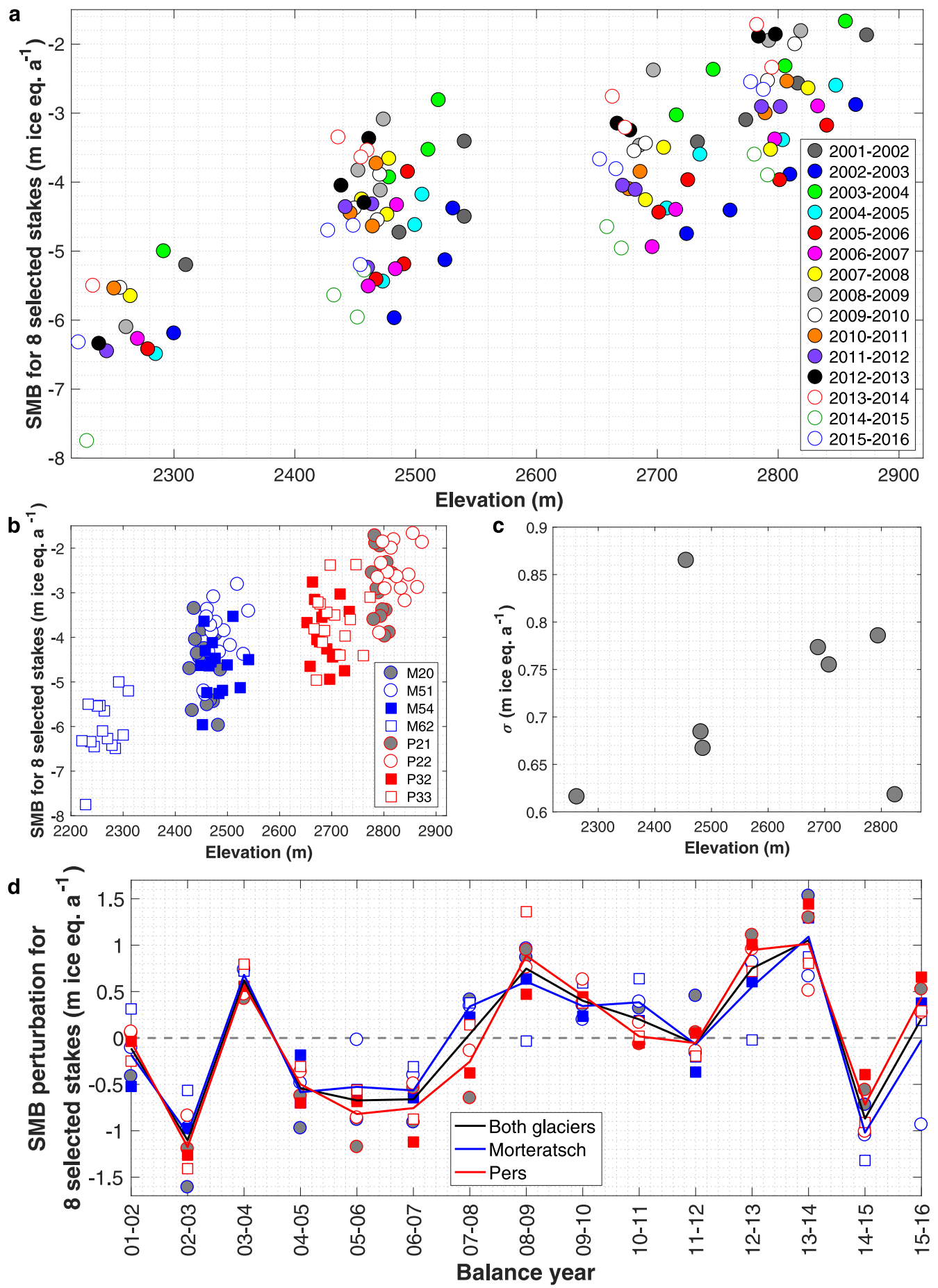

Fig. 4. (a) Annual surface mass balance against elevation for different years for the eight selected stakes (before projection to initial elevation); (b) annual surface mass balance against elevation for the eight selected stakes (before projection to initial elevation); (c) standard deviation ( $\sigma$ ) per stake over the 15-year period; (d) SMB perturbation for the eight selected stakes for the whole glacier complex and for both glaciers separately. The circles and squares correspond to the individual stakes (cf. panel b).

In our MLRA, we opt for the mean monthly temperature and not for the monthly average of the daily maxima, as air temperature can also cause melt during the night time (cf. Letréguilly, 1988). The difference between results obtained with mean monthly temperature and the monthly average of the daily maxima is however very limited as the trends in both are very similar $\left(R^{2}=\right.$ 0.97).

Table 1. Correlation $\left(R^{2}\right.$ value and $p$-value of the $F$-test) between the eight selected stakes and the mean perturbation (black line on Fig. $\left.4 \mathrm{~d}\right)$

\begin{tabular}{|c|c|c|c|c|c|c|c|c|}
\hline & M20 & M51 & M54 & M62 & P21 & P22 & P32 & P33 \\
\hline lean SMB & $\begin{array}{l}R^{2}=0.91 \\
p=3.9 \times 10^{-8}\end{array}$ & $\begin{array}{l}R^{2}=0.67 \\
p=2.0 \times 10^{-4}\end{array}$ & $\begin{array}{l}R^{2}=0.90 \\
p=5.5 \times 10^{-8}\end{array}$ & $\begin{array}{l}R^{2}=0.62 \\
p=5.1 \times 10^{-4}\end{array}$ & $\begin{array}{l}R^{2}=0.85 \\
p=8.8 \times 10^{-7}\end{array}$ & $\begin{array}{l}R^{2}=0.89 \\
p=1.5 \times 10^{-7}\end{array}$ & $\begin{array}{l}R^{2}=0.86 \\
p=7.6 \times 10^{-7}\end{array}$ & $\begin{array}{l}R^{2}=0.91 \\
p=3.3 \times 10^{-8}\end{array}$ \\
\hline
\end{tabular}




\section{METEOROLOGICAL DATA MLRA}

\subsection{Variable selection}

Initially, meteorological variables that best describe the observed SMB are considered as time clusters, i.e. as continuous time periods (4.2.), which is in line with most previous studies. Subsequently, a new method is introduced, where all possible monthly combinations (full-spectrum analysis) are considered for describing the observed SMB signal (4.3.). For all MLRAs, the goal is to describe most of the observed $\mathrm{SMB}$ variance, by using as few predictor variables as possible. Adding additional predictor variables increases the fraction of the SMB variation that can be explained, but reduces the degrees of freedom. To assess whether it is justified adding additional predictors (i.e. to avoid overfitting), the $p$-value of the $F$-test is considered, which should be as low as possible.

\subsection{Continuous time periods}

Annual periods are used at first (4.2.1.), after which a subdivision is made into half-years (4.2.2.), seasons (4.2.3.) and finally months (4.2.4.).

\subsubsection{Annual time period}

As a first test, the mean annual temperature $\left(T_{\text {ann }}\right)$ and the total annual precipitation $\left(P_{\text {ann }}\right)$ are used to explain the observed SMB variation (i.e. MLRA with 13 error degrees of freedom). An MLRA between these two variables and the measured SMB reveals that $\sim 22 \%$ of variance in SMB can be explained by these annual anomalies $\left(R^{2}=0.22\right.$, see Fig. 5a and Table 2). The weak significance of this model in describing the measured SMB variance is reflected in the high $p$-value for the $F$-test (0.229). Despite the weak correlation, the signs of the variables are logical, being negative for $T_{\text {ann }}(-0.35$, negative correlation between temperature and $\mathrm{SMB})$ and positive for $P_{\text {ann }}(+0.20$, positive correlation between precipitation and $\mathrm{SMB}$ ).

\subsubsection{Half-year time period}

In the second step, the year is subdivided in a winter half-year (WHY), consisting of fall (OND: October-NovemberDecember) and winter (JFM: January-February-March), and a summer half-year (SHY), which consists of spring (AMJ: AprilMay-June) and summer (JAS: July-August-September). These monthly clusters rather agree with the glaciological seasons than with the meteorological seasons. They are chosen so that the fall season (OND) starts just after the field measurements, broadly corresponding to the beginning of the accumulation season (i.e. the beginning of the water/hydrological year).

From the MLRA, the importance of the SHY temperature $\left(T_{\mathrm{SHY}}\right)$ is clear, as this predictor variable alone already explains $35 \%$ of the observed SMB variance $\left(R^{2}=0.35\right)$. Without this variable, almost none of the SMB variance can be explained in a MLRA with two predictor variables $(<4 \%$; $p$-values $F$-test above 0.8$)$ (Table 2$)$. The SHY temperature and the WHY precipitation account for almost half of the observed SMB variance $(46.4 \%$, Fig. 5b), which rejects the null hypothesis (no linear correlation) at the 5\% level ( $p$-value $F$-test 0.024 ), but which still leaves a very large part of the SMB unexplained. The larger absolute regression coefficient $T_{\mathrm{SHY}}(-0.51)$ compared with $P_{\mathrm{WHY}}$ (0.25) indicates a relatively higher importance of the SHY temperature. This is also supported by the fact that the SHY
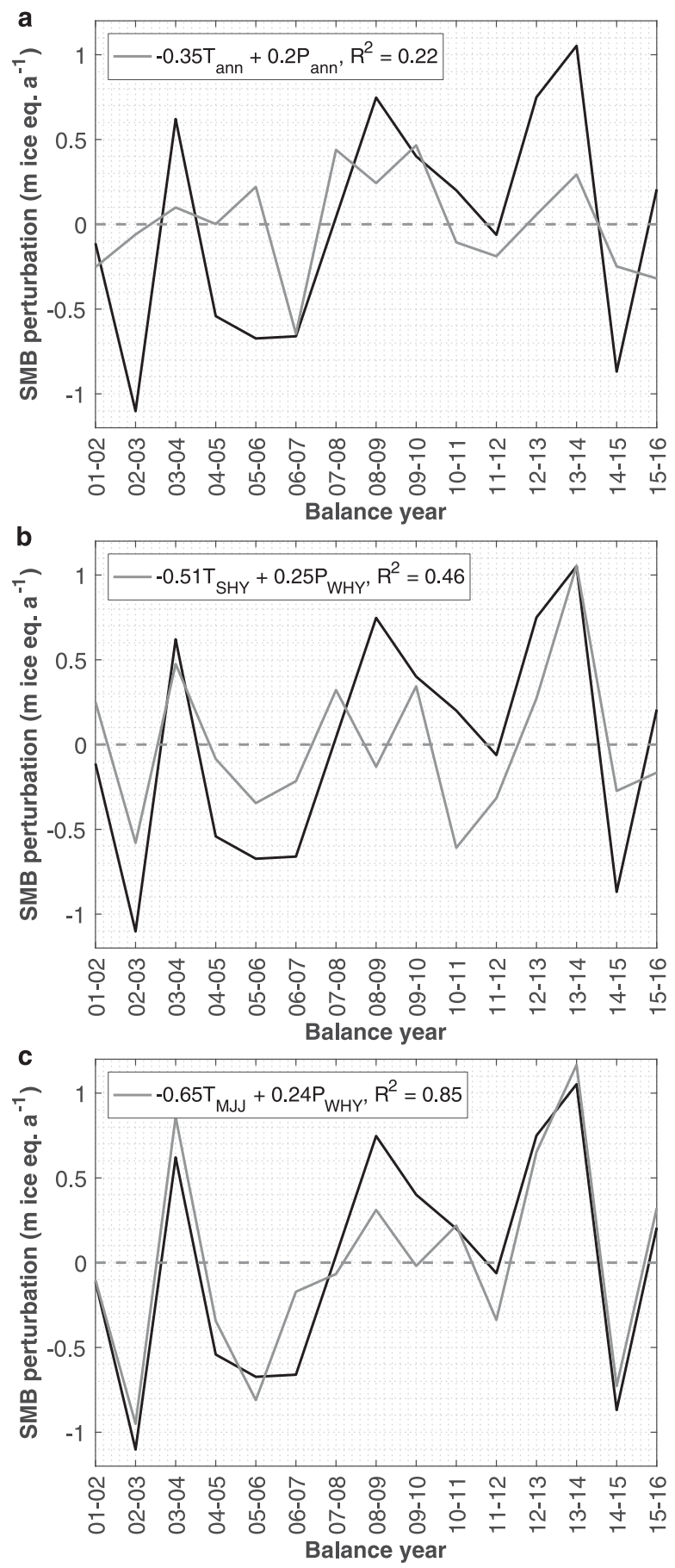

Fig. 5. Observed SMB perturbation and modelled SMB perturbation based on multiple linear regression analysis (MLRA) using the following two predictors: (a) annual temperature $\left(T_{\text {ann }}\right)$ and annual precipitation $\left(P_{\mathrm{ann}}\right)$, (b) summer half-year temperature $\left(T_{\mathrm{SHY}}\right)$ and winter half-year precipitation $\left(P_{\mathrm{WHY}}\right)$, (c) average May, June, July temperature $\left(T_{\mathrm{MJJ}}\right)$ and winter half-year precipitation $\left(P_{\mathrm{WHY}}\right)$. The black line is the observed SMB (cf. black line in Fig. 4d), the grey line is the calculated SMB signal resulting from the MLRA.

temperature combined with the (supposedly) not very relevant $\mathrm{SHY}$ precipitation can explain almost a similar fraction of the observed SMB variance $\left(R^{2}=0.39\right.$, see Table 2$)$.

\subsubsection{Seasonal time period}

In this analysis, the predictor variables were split up in seasonal components, i.e. spring (AMJ), summer (JAS), autumn 
Table 2. Multiple linear regression analysis (MLRA) between z-score standardised meteorological variables (averaged over Segl-Maria and Samedan) and observed SMB perturbations for eight selected stakes covering the period 2001-2016

\begin{tabular}{llr}
\hline Time period & Best-fit multilinear correlation & $R^{2}$ \\
\hline Annual & $\mathrm{SMB}=-0.35 T_{\text {ann }}+0.20 P_{\text {ann }}$ & 0.22 \\
Half-year & $\mathrm{SMB}=-0.09 T_{\mathrm{WHY}}+0.002 P_{\mathrm{WHY}}$ & 0.229 \\
& $\mathrm{SMB}=-0.14 T_{\mathrm{WHY}}+0.10 P_{\mathrm{SHY}}$ & 0.04 \\
& $\mathrm{SMB}=-0.51 T_{\mathrm{SHY}}+0.25 P_{\mathrm{WHY}}$ & 0.893 \\
Seasonal & $\mathrm{SMB}=-0.44 T_{\mathrm{SHY}}-0.14 P_{\mathrm{SHY}}$ & 0.024 \\
& $\mathrm{SMB}=-0.47 T_{\text {spr }}+0.14 P_{\mathrm{SHY}}$ & 0.39 \\
Individual months (continuous) & $\mathrm{SMB}=-0.49 T_{\text {spr }}-0.21 T_{\text {sum }}+0.23 P_{\mathrm{SHY}}$ & 0.46 \\
& $\mathrm{SMB}=-0.65 T_{\text {Mayjunjul }}+0.24 P_{\mathrm{WHY}}$ & 0.025
\end{tabular}

(OND) and winter (JFM). Combined with the possibility of still using the variables at the half-year time period (WHY and SHY, see previous section), this allows for $36\left(6^{2}\right)$ possible combinations for MLRAs with one temperature and one precipitation predictor variable. With two predictor variables, most of the SMB variability is described by the SHY temperature and the WHY precipitation (cf. Section 4.2.2.), followed by combining the spring temperature and the WHY precipitation $\left(R^{2}=0.46, p\right.$-value of $F$-test $\left.=0.0251\right)$. With three predictor variables, most of the variation can be described through the spring and summer temperature normalised anomalies as two separate variables and the WHY normalised precipitation anomaly as one variable: $\mathrm{SMB}=-0.49 T_{\text {spr }}-0.21 T_{\text {sum }}+0.23 P_{\mathrm{WHY}}$. The $R^{2}$-value of 0.55 is higher than the one for the model based on $\mathrm{T}_{\mathrm{SHY}}$ and $\mathrm{P}_{\mathrm{WHY}}$ (see Section 4.2.2.), but the $p$-value of the $F$-test (0.0286) is also higher (suggesting overfitting) as the error degrees of freedom are in this case reduced to 12 (vs 13 in the previous analysis). Although the correlation remains relatively low, which suggests that a more refined choice of time periods is needed, the regression coefficients indicate a larger importance for spring temperature compared with the summer temperature.

\subsubsection{Monthly time period}

A more in-depth analysis, where all different combinations of clustered (subsequent) months are allowed, suggests that the $\mathrm{SMB}$ variance is best described by the average May-JuneJuly temperature $\left(T_{\mathrm{MJJ}}\right)$ and the total precipitation from October to March (i.e. the WHY precipitation, Table 2). This MLRA is statistically very significant ( $p$-value $F$-test of $1.02 \times 10^{-5}$ ) and accounts for $85.3 \%$ of the variance in measured SMB (Fig. 5c), with a clear dominance of the MJJ temperature (regression coefficient of -0.65) compared with the WHY precipitation (regression coefficient of 0.24 ).

\subsection{Discontinuous time periods (full-spectrum analysis)}

MLRAs are now performed between the SMB series and all possible monthly combinations of temperature and precipitation. This new setup is still based on two predictor variables, i.e. one for temperature and one for precipitation, and the error degrees of freedom are therefore still equal to 13. For each MLRA, a different combination of temperature and precipitation months is selected and analysed, resulting in a total of 16.8 million $\left(=2^{24}\right)$ combinations. The total number of combinations arises from combining all the 24 different variables, 12 for the temperature months and 12 for the precipitation months, in every possible way. Performing such a large number of MLRAs is now possible because of increased computational power, which was a limiting factor in the past (e.g. Letréguilly, 1988). For each MLRA, the temperature predictor variable is the mean temperature of the selected temperature months, while the precipitation variable is the precipitation sum of all selected precipitation months. As was the case for the continuous time period MLRAs (Section 4.2.), both predictor variables are expressed as anomalies through a z-score conversion to allow for a direct comparison of their individual contribution to explain the SMB series.

The $R^{2}$ values of the $2^{24}$ MLRAs have a right-skewed distribution (skewness of +0.759 ), with a peak at $R^{2}=0.1-0.12$ (see Fig. 6a). $R^{2}$ values range between 0 and 0.9086 . The highest $R^{2}$ value $(0.9086)$ is obtained from the mean May-June-July-October-November temperature and the February-May-June-December precipitation. This obtained unique combination is however very sensitive to even small changes in observed SMB, and it is therefore more relevant to consider an ensemble of combinations. The $50 \mathrm{com}-$ binations that best describe the observed SMB variance (Fig. 6b; Fig. 7), i.e. the ones with the highest $R^{2}$ values $\left(R^{2}>0.86088\right)$, have a clear monthly pattern. For all $50 \mathrm{com}-$ binations, the June and July temperatures are included (100\% probability inclusion (p.i.)), while 49 combinations include the May temperature (98\% p.i.) (Fig. 6c). Subsequently, the October temperature $(40 \%$ p.i.) and November temperature (24\% p.i.) sometimes appear in the top 50 combinations, but for all other months, the effect of the temperature on the $\mathrm{SMB}$ variations is close to negligible. For precipitation all months are well represented in the top 50 combinations, except for July and August (Fig. 6d). The most crucial months seem to be those before and at the onset of the ablation season (February-March-April-May-June) and those at the beginning of the accumulation season - early winter (October-November-December).

When considering the top $0.1 \%$ of all combinations, which corresponds to the 16777 combinations with an $R^{2}$ value higher than 0.73599 , the importance of the monthly temperatures remains almost unaltered (Fig. 6e). July is the most common month in this selection $(98.8 \%$ p.i.), closely followed by May (93.3\% p.i.), June (92.4\% p.i.), and subsequently by October $(57.9 \%$ p.i.) and November $(37.2 \%$ p. i.). For the precipitation, the importance of the individual months changes slightly when considering this larger ensemble of combinations (Fig. 6f) compared with the top 50 combinations (Fig. $6 \mathrm{~d}$ ). The summer months still have a slightly more limited contribution to the observed SMB, but for the other months, no clear pattern is obtained and all months 

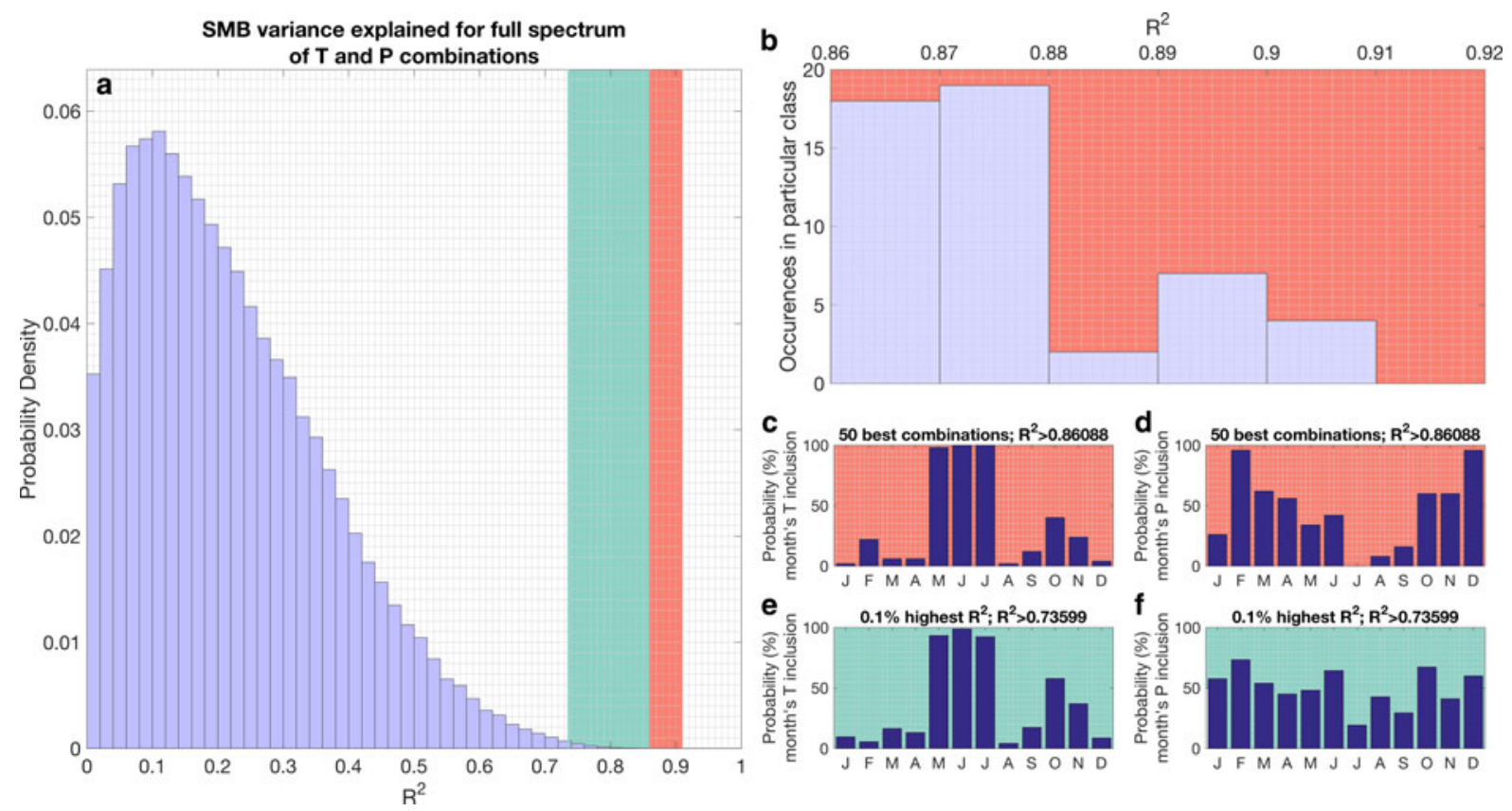

Fig. 6. (a) Probability density of $R^{2}$ values for MLRA for all (16.8 million) possible combinations of months. The green area corresponds to $R^{2}$ range between 0.74 (lower limit $0.1 \%$ highest $R^{2}$ values) and 0.86 (lower limit 50 highest $R^{2}$ combinations), the red area is the range of the 50 combinations with the highest $R^{2}$ value. (b) Zoom on the 50 MLRAs with highest $R^{2}$ values, which are visually non-detectable in (a). (c) and (d) Probability that a particular month's temperature or precipitation is included in the 50 combinations with highest $R^{2}$ value. (e) and (f) Probability that a particular month's temperature or precipitation is included in the top $0.1 \%$ combinations (16 777 combinations) with the highest $R^{2}$ value.

have a fairly similar occurrence in the $0.1 \%$ top combinations (varying between 41.2 and $73.5 \%$ p.i.).

\section{DISCUSSION}

\subsection{Robustness correlations and time-series length}

The MLRAs performed for different time periods (annual, half-year, seasonal and monthly) are mutually consistent, which indicates that the correlations are robust. The fullspectrum method, in which discontinuous periods are also considered, supports this, and the dominant months from the continuous time period analysis (May, June, July

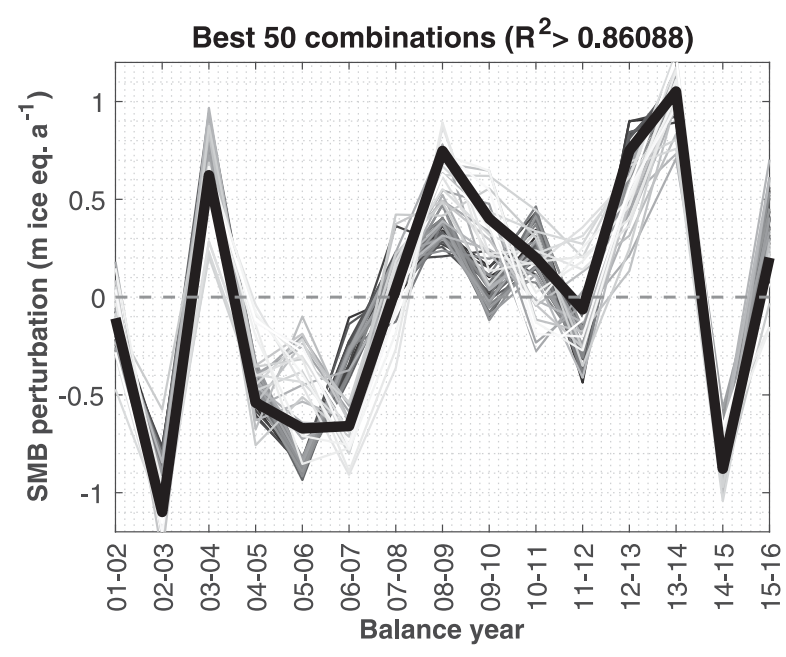

Fig. 7. SMB reconstruction for the top 50 combinations (see Fig. 6bd). The thick black line represents the observed SMB perturbation (cf. Fig. 5) and the grey lines represent the 50 best combinations (the greyer the higher the $R^{2}$, the whiter the lower the $R^{2}$ ). temperature and WHY precipitation) are confirmed. Furthermore, the importance of other months' temperature (October, and to a lesser extent November) and precipitation (spring: April, May, June) also appears.

The robustness and significance of the results is supported by statistical evidence. For the best models, low $p$-values for the $F$-test and high $R^{2}$-values are obtained $\left(R^{2}>0.86\right.$ for the best 50 combinations of the full-spectrum analysis). In contrast, when performing the full-spectrum analysis with series of random SMB data and/or meteorological data, the 50 best combinations of monthly meteorological variables are typically only able to explain between 50 and $70 \%$ of the SMB variance, significantly less than the $86 \%$ found here from the real data.

The length of the record, 15 years, is thus sufficient to obtain meaningful regression coefficients. The main finding of a very limited effect of August and September temperature in fact already appears when a period of 10 years (e.g. 2001-2011) is considered (not shown here). The sufficient length of the 15-year record agrees with the findings by Letréguilly and Reynaud (1989) who state that at least 10 years are needed to obtain qualitative regression coefficients, and Vincent and Vallon (1997) who mention a 5-10-year period as a minimum.

\subsection{Temperature dominance}

The results from the MLRAs indicate that there is a strong correlation between temperature and observed SMB, which is the cornerstone for various widely used simplified SMB models (e.g. Reeh, 1989; Hock, 2003; Braithwaite and others, 2013). This strong SMB dependence on temperature is also in line with the findings from a previous simple surface energy balance (SEB) modelling study on the Morteratsch glacier (Nemec and others, 2009). Nemec and others (2009) parameterised the longwave radiation and the 
turbulent heat fluxes as a function of temperature (cf. Oerlemans, 2001) and were able to closely reproduce the observed SMB.

The SEB in the ablation area of the Morteratsch glacier complex is mainly driven by the radiation components and the sensible heat flux, while the latent heat flux is much smaller (Klok and Oerlemans, 2002, 2004). Notice that this is strongly related to the climatic conditions and the location of the glacier (mid-latitude maritime glacier), and in other settings (e.g. continental, polar, tropical), the importance of the individual SMB components may strongly vary (e.g. Benn and Evans, 2010). The fact that temperature explains a very large fraction of the observed SMB variations partly results from its direct influence on the sensible heat flux, which is one of the dominant fluxes in the glacier SEB. Furthermore, temperature correlates with the short-wave radiation component, as a higher temperature leads to surface melt and lowers the surface albedo, which in turn increases the net shortwave radiation. The longwave radiation, despite being the first source of the energy balance (Klok and Oerlemans, 2002), has a limited interannual variability and is therefore of limited importance when considering SMB variations over time (cf. Sicart and others, 2008).

MLRAs in which additionally radiation components are considered (e.g. Lefauconnier and others, 1999) hardly improve the fraction of the observed SMB that can be explained. For instance, if the total monthly hours of sun are added to the analysis, the fraction of the SMB variance that can be explained is almost unaltered. The monthly hours of sun are not significant at the $5 \%$ significance level given the other terms (temperature and precipitation for selected months) in the MLRA. Notice that the same is true when a second temperature variable is introduced (i.e. working with three predictor variables), adding additional complexity to the MLRA, with limited to no added value (case of overfitting, as the $p$-value of the $F$-test increases).

\subsection{Limited effect of mid- to late-summer conditions on SMB variability}

In the ablation area of alpine glaciers, most of the surface mass loss occurs during summer, which at the monthly time period used in this study corresponds to July, August and September. During this period, the snow cover that protects the glacier through its high albedo is removed and the glacier ice (low albedo) is directly exposed. Due to its lower albedo, an ice-covered surface absorbs more of the incoming radiation compared with a snow-covered surface and therefore experiences more melt.

According to the MLRA conducted here, the meteorological conditions in August and September have a very limited effect on the interannual SMB variability, as models without these components are able to explain more than $90 \%$ of the observed changes in SMB (Fig. 6). The precipitation during these 2 months typically occurs as rain and also the temperature of these months was found to have a very limited contribution to the observed SMB variability. On the other hand, the WHY precipitation and the meteorological conditions at the start and at the end of the ablation season have a much larger effect on the interannual SMB variability in the ablation area of the Morteratsch glacier complex. The latter corresponds to the mid- to late-spring precipitation (April, May), the late-spring to early-summer temperature (May, June, July) and early-autumn precipitation and temperature (October). The WHY precipitation determines the winter balance and determines the thickness of the snow pack at the beginning of the ablation season. The May-June-July temperatures subsequently determine the snow ablation intensity and the precipitation type (snow/ rain). A lower mean monthly temperature increases the chance of a precipitation event being a snowfall event, which increases the SMB. The importance of autumn (October and to a lesser extent November) conditions is not surprising, as this period largely determines the transition from the ice-covered to the snow-covered ablation area. Often ice melt still occurs after the SMB measurements (late September to early October), as field observations determined that the ablation area is often not entirely snowcovered at this time.

The results from the MLRAs thus suggest that the length of the ablation season, rather than its intensity, determine the interannual SMB variability here. This is related to the interannual melt differences between the summer seasons, which are believed to be much smaller than the intra-annual contrast between snow and ice melt (contrast between the seasons) (cf. Durand and others, 2009; Thibert and others, 2013). Results from a straightforward positive-degree-day (PDD) calculation support the dominant effect of the ice ablation season duration on the glacier's ablation area $\mathrm{SMB}$. The PDD model is run at an hourly time step, and the $2 \mathrm{~m}$ temperature at each stake is derived from an interpolation between measured temperatures at Samedan (1708 m) and Corvatsch $(3302 \mathrm{~m})$. Precipitation is upscaled from Samedan with an elevation gradient of $1.0 \mathrm{~mm}$ w.e. $\mathrm{m}^{-1}$, based on field measurements in the glacier's accumulation area (Sodemann and others, 2006; Nemec and others, 2009). A distinction is made between snowfall and rainfall depending on the air temperature. The degree-day factors (DDF) for snow and ice are calibrated in order to minimise the RMSE between observed and modelled SMB. For the eight stakes over the 15-year period, an RMSE of $0.385 \mathrm{~m}$ w.e. $\mathrm{a}^{-1}$ is obtained (Fig. 8a) with a DDF for snow/ice of 2.8/5.4 mm ice eq. per degree day for the Morteratsch glacier, and 3.5/6.6 mm ice eq. per degree day for the Pers glacier. These DDFs are in good agreement with the values found for other glaciers in the European Alps (e.g. Hock and others, 1999). Despite the PDD model's simplicity (e.g. shading effects from the surrounding mountains and refreezing/retention of meltwater in the snowpack are not accounted for), the observed SMB (Fig. 8a) and its interannual variability $\left(R^{2}=0.93\right.$, Fig. $\left.8 \mathrm{~b}\right)$ are closely reproduced. The PDD model indicates that the number of ice ablation days (averaged over the eight stakes) is strongly anticorrelated with the SMB perturbation (Fig. 8c). The variation in ice ablation days is $\sim 70 \%$ anticorrelated to the modelled SMB variance $\left(R^{2}=-0.71\right)$ and $60 \%$ anticorrelated to the observed SMB $\left(R^{2}=-0.60\right)$. The PDD simulations furthermore indicate that the temperature in the early- and late-ablation season has the largest influence on the ice ablation season length (Fig. 8d, shown for a temperature bias of -1 and $\left.+1{ }^{\circ} \mathrm{C}\right)$. The effect of changes in the July temperature on the ice ablation season length is found to be limited, as this is usually the warmest month of the year.

The importance of the WHY precipitation and earlyand late-ablation season meteorological conditions is also clear when analysing the 2 years with the lowest SMB (2002-03 and 2014-15) and the 3 years with the highest 

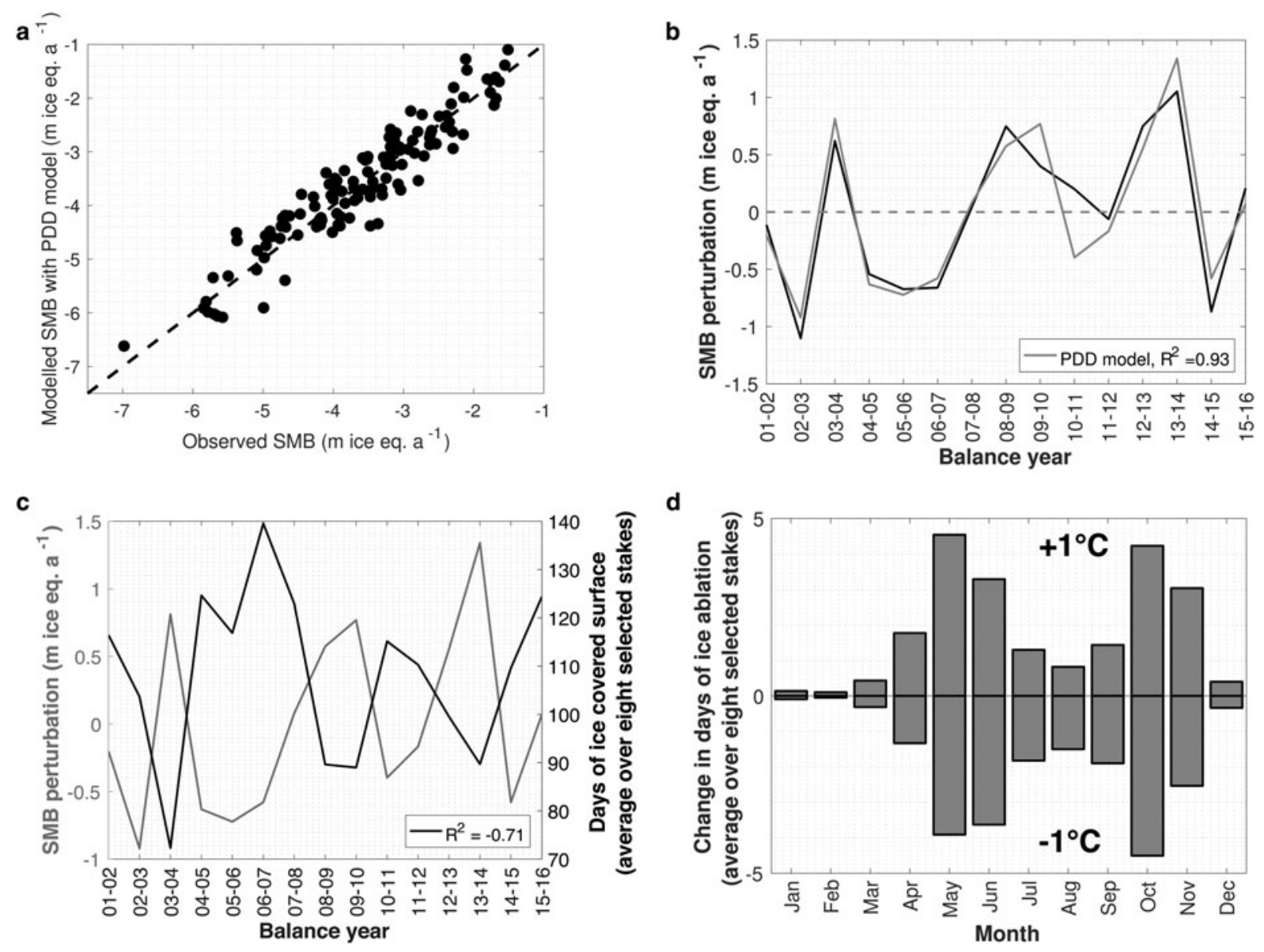

Fig. 8. (a) Observed vs modelled annual SMB through a PDD approach for the eight selected stakes over the 15-year period. (b) Observed SMB perturbation (black line, cf. Fig. 5) and PDD modelled (grey line) SMB perturbation. (c) PDD modelled SMB perturbation (grey line) and days of ice ablation (averaged over eight selected stakes, black line). (d) Change in number of ice ablation days for a monthly temperature increase/decrease of $1^{\circ} \mathrm{C}$, as obtained from the PDD model.

SMB (2003-04, 2012-13 and 2013-14) (Table 3). The lowest SMB (2002-03) over the period can be explained by the 2003 European heat wave (Beniston, 2004; García-Herrera and others, 2010) (z-score of 1.41 for $\left.2003 T_{\text {sum }}\right)$, but also the high temperatures in October 2002 and May 2003 have had an important role (z-score of 1.58 for TOctMayjunjul). Notice that the 2002-03 SMB year also had a high winter precipitation $(524.4 \mathrm{~mm}$ vs an average of $308.8 \mathrm{~mm}, \mathrm{z}$-score of 1.89 ), but this is almost entirely due to the extremely high November precipitation, which is the highest monthly precipitation for the entire period considered in this study 16-year period (392.2 mm, see Fig. 2). A substantial fraction of the precipitation occurred on November 14-16 when temperatures in the ablation area of the glacier were varying between -3.5 and $+3.5^{\circ} \mathrm{C}$ (Fig. 9). It is therefore likely that (a part of) the precipitation over this time period did not occur as snow, which illustrates the aforementioned role of autumn temperatures in delimiting the rain/snowfall regime. The snow accumulation that may have occurred in November likely melted during late autumn and early winter, which winter had moreover a very dry period later on $\left(P_{\mathrm{Dec} \rightarrow \text { Mar }}\right.$ for this balance year is the lowest of the record, 58.8 vs $136.3 \mathrm{~mm}$ on average; z-score of -1.26). The year with the second most negative SMB (2014-15) had similar average temperatures for the months of May-June-July-October as 2002-2003, but probably the SMB was slightly less negative due to the higher December-March precipitation, which was close to average (133.6 mm, z-score of -0.05 ).

Table 3. Meteorological variables averaged over the stations of Samedan and Segl-Maria for the 2001-2016 period for selected years. Values between brackets indicate the respective $z$-score of the values

\begin{tabular}{|c|c|c|c|c|c|c|}
\hline & $\begin{array}{l}\text { 2001-2016 } \\
\text { Average }\end{array}$ & $\begin{array}{l}\text { 2002-03 } \\
\text { (Lowest SMB) }\end{array}$ & $\begin{array}{l}2014-15 \\
\text { (Second lowest SMB) }\end{array}$ & $\begin{array}{l}\text { 2003-04 } \\
\text { (Third highest SMB) }\end{array}$ & $\begin{array}{l}\text { 2012-13 } \\
\text { (Second highest SMB) }\end{array}$ & $\begin{array}{l}\text { 2013-14 } \\
\text { (Highest SMB) }\end{array}$ \\
\hline$T_{\text {spr }}\left(T_{\text {AprMayjun }}\right)\left({ }^{\circ} \mathrm{C}\right)$ & 6.44 & $7.58(1.52)$ & $6.68(0.32)$ & $5.52(-1.23)$ & $5.28(-1.54)$ & $6.02(-0.56)$ \\
\hline$T_{\text {sum }}\left(T_{\text {JulAugSep }}\right)\left({ }^{\circ} \mathrm{C}\right)$ & 10.69 & $11.72(1.41)$ & $11.58(1.22)$ & $10.60(-0.12)$ & $11.05(0.50)$ & $9.65(-1.42)$ \\
\hline$T_{\text {MayjunJulOct }}\left({ }^{\circ} \mathrm{C}\right)$ & 8.34 & $9.51(1.58)$ & $9.53(1.59)$ & $6.88(-1.96)$ & $7.58(-1.03)$ & $7.82(-0.70)$ \\
\hline$P_{\mathrm{WHY}}(\mathrm{mm})$ & 308.8 & $524.4(1.89)$ & $436.1(1.12)$ & $302.9(-0.05)$ & $258.5(-0.44)$ & $467.1(1.39)$ \\
\hline$P_{\text {Dec }- \text { Mar }}(\mathrm{mm})$ & 136.3 & $58.8(-1.27)$ & $133.6(-0.05)$ & $109.05(-0.45)$ & $95.1(-0.67)$ & $287.85(2.48)$ \\
\hline
\end{tabular}




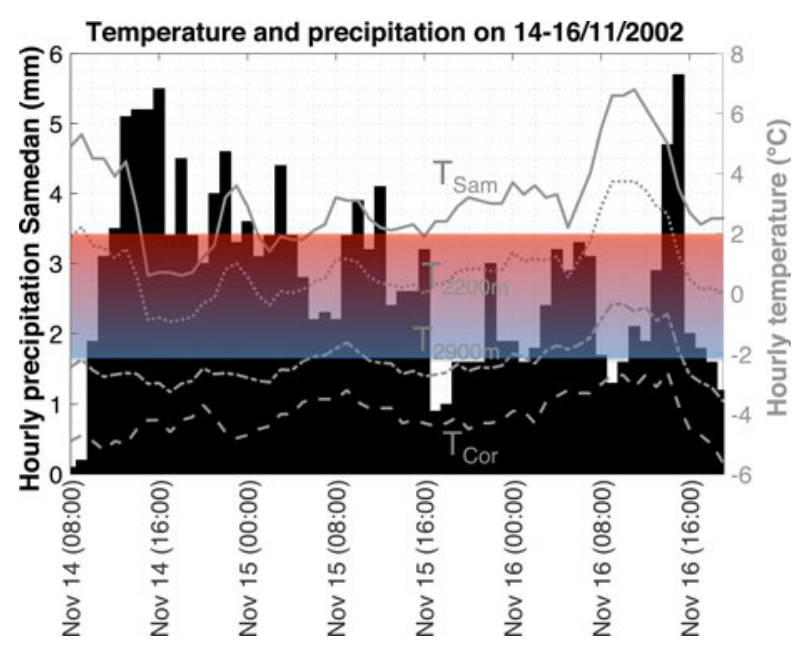

Fig. 9. Hourly precipitation at Samedan meteorological station and hourly temperature at Samedan meteorological station $(1708 \mathrm{~m})$ and Corvatsch meteorological station (3302 m). Temperature series at $2200 \mathrm{~m}$ (lowest elevation of SMB measurements) and $2900 \mathrm{~m}$ (highest elevation of SMB measurements) are derived through linear interpolation between the Samedan and Corvatsch series. The shaded area roughly corresponds to the rain/snow threshold.

The 3 years with the highest SMB (2003-04, 2012-13 and 2013-14) are all characterised by low average May-JuneJuly-October temperatures. The limited importance of August and September temperatures on the SMB variability is also illustrated by the relatively high SMB for the years 2003-04 and 2012-13, which years respectively had an average (z-score of -0.05) summer (July-August-September) and an above-average warm summer $\left(11.05\right.$ vs $10.69^{\circ} \mathrm{C}$ on average, $z$-score of 0.50 ). The most positive SMB year, 2013-14, had relatively low May-June-July-October temperatures, and here the very high $P_{\mathrm{WHY}}$ (z-score of 1.39)/ $P_{\text {Dec-Mar }}$ (z-score of 2.48) played a major role.

\subsection{Comparison to other studies}

Most studies correlating temperature and precipitation data to SMB variations found summer temperatures to be the key component. Martin (1978) explained 77\% $\left(R^{2}=0.77\right)$ of the 1949-75 SMB variance of Glacier de Sarennes by means of maximum summer temperature, precipitation from October to May and a June precipitation component (three predictor variables). For glaciers in the Swiss Alps, Chen and Funk (1990) used the mean summer temperature and the mean annual precipitation to describe the SMB variations and with this they could explain between 49 and $81 \%$ of the observed variance. For these studies on Alpine glaciers, the temperature variations dominate the SMB compared with the precipitation variations, which is also the case in our analysis and confirmed in other SMB modelling studies (e.g. Oerlemans and Reichert, 2000). In a study on Austre Brøggerbreen (Svalbard) (Lefauconnier and Hagen, 1990), $77 \%$ of the 19 -year net SMB series is explained by the July and August PDDs, which are a measure for air temperature, combined with precipitation from October to May. Later this was updated to $66 \%$ of the SMB variance being explained for a 28-year time series by Lefauconnier and others (1999). In a recent study, Trachsel and Nesje (2015) analysed the SMB of eight Scandinavian glaciers using statistical models and found that summer temperature and winter precipitation explained more than $70 \%$ of the variance for maritime glaciers, and between 50 and $70 \%$ for continental glaciers.

It is noteworthy that the early- and late-ablation season conditions (e.g. temperatures and precipitation in April, May, June and October), which are key in explaining the SMB variations for the Morteratsch glacier complex, are never included in the above analyses. An exception is the study by Letréguilly (1988) where the June and July temperatures (without August and September) are combined with the October-March precipitation to explain $\sim 70 \%$ of the SMB variations for Peyto glacier (Rocky Mountains, Canada). In the same study, the late-spring conditions ( $T_{\text {May,June,Jul,Aug }}$ and $\left.P_{\text {Oct } \rightarrow \text { May }}\right)$ are also incorporated to explain $65-75 \%$ of the SMB variations for Sentinel glacier and Place glacier (Coast Mountains, Canada).

Important to note as well is that the above-mentioned studies consider the glacier-wide SMB, while our analysis is based on stakes only from the glacier's ablation area. In the accumulation area, the snow-ice cover contrast is not present, but also here a seasonal albedo contrast exists. The winter and spring fresh snow have a high albedo, but as the summer advances the snow cover metamorphoses and becomes dirtier (Oerlemans and others, 2009), which in combination with melt and rainfall events (Oerlemans and Klok, 2004) leads to an albedo decrease. Therefore, the differences between the ablation area SMB signal and the glacier-wide SMB signal are expected to be limited. The difference between our results, with a limited effect of August and September conditions and other studies is therefore also believed to be partly linked to differences in methodology (e.g. point measurements vs glacier-wide SMB, see further) and the full spectrum of monthly combinations considered here.

Also for the continuous month approach (4.2.4), i.e. the classic approach, the correlations obtained are very high for our 15-year record (Fig. 5c) compared with other studies. This may again be linked to opting for a different variable than the widely used June-July-August temperatures (here May-June-July is used), but may in part also be related to the quality and homogeneity of the data used in this study. First of all, the data from the MeteoSwiss stations is from a recent period and highly reliable, which is not always the case in earlier studies, as argued for instance by Letréguilly (1988). Especially older temperature and precipitation measurements contain biases and need to be corrected to homogenise the time series (e.g. Böhm and others, 2010). Second, the systematic error on the Morteratsch SMB is believed to be relatively limited and similar in magnitude over time, as all measurements occurred by the same group of scientists, using the same methodology and with the same materials. This is often not the case and for extended periods of time, the measurement errors can be very large, up to $20-40 \mathrm{~cm}$ and even more for older stakes (Letréguilly and Reynaud, 1989). Finally, we opted to correlate the meteorological data directly to our SMB measurements, instead of using a spatially averaged/ glacier-wide SMB (cf. Vincent and others, 2017). The eight stakes used in this study cover the whole period and move only very little, which is corrected with high-precision GPS measurements. Other studies consider spatially averaged SMB or (partially) modelled SMB, which adds an additional uncertainty. 


\section{CONCLUSION AND OUTLOOK}

In this study, we analysed a dataset consisting of 15 years of SMB measurements in the ablation area and around the ELA of the Morteratsch glacier complex, and attempted to describe the SMB variability through a minimal statistical approach. The observed interannual SMB variance is very similar for both glaciers and can largely be explained $(>90 \%)$ by combining monthly temperature and precipitation data from nearby meteorological stations. The fact that almost the entirety of the SMB variance can be explained by a simple MLRA with one temperature and one precipitation variable makes it redundant to add additional predictor variables (e.g. radiation, additional temperature or precipitation variable) to the analysis. The full-spectrum method introduced in this study relies on increased computational power, which was a limiting factor in the past, and considers the contribution of every month's temperature and precipitation, which are combined in these two predictor variables. The MLRA indicates that the spring-/early-summer and autumn meteorological conditions play a crucial role, as they determine the length of the ablation season. High temperatures and low precipitation in spring advance the transition from a snow- to an ice-covered surface, while in autumn they favour a prolonged ice ablation season. Furthermore, temperatures during these months also influence the SMB perturbation by affecting the precipitation type (rain/snow) over the ablation area of the glacier. The mid- to late-summer (August and September) conditions are found to have only a minor effect on the annual SMB perturbation. These findings are supported by output from a simple PDD model, indicating that early- and late-melting season meteorological conditions are the main drivers for the ice ablation season duration, which is itself strongly anticorrelated to the SMB perturbation. The widely used June-July-August (JJA) temperature index may therefore not always be the most appropriate variable to describe SMB variability through statistical correlation.

Applications of the full-spectrum method to other glaciers and other SMB series will be useful to better understand the meteorological station representativeness, the impact of their distance to the measurements and contrasts between ablation/accumulation measurements and seasonal/annual SMB measurements. Through its minimal character, relying on as few predictor variables as possible, the method is an interesting alternative/complementary approach to the more classic, well-established stepwise selection procedures (e.g. Tinsley and Brown, 2000; Whittingham and others, 2006). In future works, the threshold delimiting the 'best' combinations (here set at the best 50 combinations and the top $0.1 \%$ combinations) will have to be investigated and could potentially be changed for other studies. In this study, the temperature dependence is very clear, but this is less the case for precipitation. For the latter, the monthly signal changes as the threshold changes, which is related to the fact that the precipitation contributes less to the observed SMB variance than the temperature. Possible extension of the method presented here could for instance separate between the SMB in the ablation and accumulation area, or between winter and summer $\mathrm{SMB}$, if the necessary measurements are available.

\section{SUPPLEMENTARY MATERIAL}

The supplementary material for this article can be found at https://doi.org/10.1017/jog.2018.18

\section{ACKNOWLEDGEMENTS}

We are grateful to everyone who helped to collect the SMB data on the Morteratsch glacier complex over the past 15 years and thank MeteoSwiss for making all meteorological data available. Harry Zekollari performed this work through a PhD fellowship of the Research Foundation Flanders (FWO-Vlaanderen) and finalised this research during a research stay at ETH Zürich, financed by a travel grant for a long stay abroad from the Research Foundation Flanders (grant No. V427216N). Matthias Huss is thanked for the fruitful discussions. We thank the Associate Chief Editor H. Jiskoot, the Scientific Editor N. Eckert, and three anonymous reviewers whose comments and suggestions greatly helped to improve the manuscript.

\section{REFERENCES}

Beniston M (2004) The 2003 heat wave in Europe: a shape of things to come? An analysis based on Swiss climatological data and model simulations. Geophys. Res. Lett., 31(2), L02202 (doi: 10.1029/2003GL018857)

Benn D and Evans DJA (2010) Glaciers and glaciation, 2nd edn. London, Hodder Arnold (doi: 10.1111/j.1502-3885.2011. 00212.x)

Berthier E and Vincent C (2012) Relative contribution of surface mass-balance and ice-flux changes to the accelerated thinning of Mer de Glace, French Alps, over 1979-2008. J. Glaciol., 58 (209), 501-512 (doi: 10.3189/2012JoG11J083)

Braithwaite RJ, Raper SCB and Candela R (2013) Recent changes (1991-2010) in glacier mass balance and air temperature in the European Alps. Ann. Glaciol., 54(63), 139-146 (doi: 10.3189/ 2013AoG63A285)

Böhm R and 5 others (2010) The early instrumental warm-bias: a solution for long central European temperature series 17602007. Clim. Change, 101(1), 41-67 (doi: 10.1007/s10584-0099649-4)

Chan JCW, Van Ophem J and Huybrechts P (2009) Estimation of accumulation area ratio of a glacier from multi-temporal satellite images using spectral unmixing. Proc. IEEE Geosci. Remote Sens. Symp., 2, 606-609 (doi: 10.1109/IGARSS.2009.5418157)

Chen J and Funk M (1990) Mass balance of Rhonegletscher during 1882/83-1986-/87. J. Glaciol., 36(123), 199-209

Church JA and 13 others (2013) Sea level change. In Stocker TF and 9 others eds. Climate change 2013: the physical science basis. Contribution of Working Group I to the Fifth Assessment Report of the Intergovernmental Panel on Climate Change. Cambridge University Press, Cambridge, UK, 1137-1216 (doi: 10.1017/CB09781107415315.026)

Cogley JG and 10 others (2011) Glossary of glacier mass balance and related terms. IHP-VII Technical Documents in Hydrology. 86, 114, Paris

Durand $Y$ and 5 others (2009) Reanalysis of 47 years of climate in the French Alps (1958-2005): climatology and trends for snow cover. J. Appl. Meteorol. Climatol., 48, 2487-2512 (doi: 10.1175/2009JAMC1810.1)

Eckert N, Baya H, Thibert E and Vincent C (2011) Extracting the temporal signal from a winter and summer mass-balance series: application to a six-decade record at Glacier de Sarennes, French Alps. J. Glaciol., 57(201), 134-150 (doi: 10.3189/ $002214311795306673)$

Farinotti D, Usselmann S, Huss M, Bauder A and Funk M (2012) Runoff evolution in the Swiss Alps: projections for selected high-alpine catchments based on ENSEMBLES scenarios. Hydrol. Process., 26(13), 1909-1924 (doi: 10.1002/hyp.8276)

Fischer M, Huss M and Hoelzle M (2015) Surface elevation and mass changes of all Swiss glaciers 1980-2010. Cryosphere, 9 (2), 525-540 (doi: 10.5194/tc-9-525-2015) 
Fischer M, Huss M, Kummert M and Hoelzle M (2016) Application and validation of long-range terrestrial laser scanning to monitor the mass balance of very small glaciers in the Swiss Alps. Cryosphere, 10(3), 1279-1295 (doi: 10.5194/tc-10-1279-2016)

Gabbi J, Carenzo M, Pellicciotti F, Bauder A and Funk M (2014) A comparison of empirical and physically based glacier surface melt models for long-term simulations of glacier response. J. Glaciol., 60(224), 1199-1207 (doi: 10.3189/2014JoG14J011)

Gabbud C, Micheletti N and Lane SN (2015) Lidar measurement of surface melt for a temperate alpine glacier at the seasonal and hourly scales. J. Glaciol., 61(229), 963-974 (doi: 10.3189/ 2015JoG14J226)

Gabbud C, Micheletti N and Lane SN (2016) Response of a temperate alpine valley glacier to climate change at the decadal scale. Geogr. Ann. Ser. A, Phys. Geogr., 98(1), 81-95 (doi: 10.1111/geoa.12124)

García-Herrera R, Díaz J, Trigo RM, Luterbacher J and Fischer EM (2010) A review of the European summer heat wave of 2003. Crit. Rev. Environ. Sci. Technol., 40(4), 267-306 (doi: 10.1080/ 10643380802238137)

Gilbert A, Vincent C, Gagliardini O, Krug J and Berthier E (2015) Assessment of thermal change in cold avalanching glaciers in relation to climate warming. Geophys. Res. Lett., 42(15), 63826390 (doi: 10.1002/2015GL064838)

Gindraux S, Boesch R and Farinotti D (2017) Accuracy assessment of digital surface models from unmanned aerial vehicles' imagery on glaciers. Remote Sens., 9(3), 186 (doi: 10.3390/rs9020186)

Hock R (2003) Temperature index melt modelling in mountain areas. J. Hydrol., 282(1-4), 104-115 (doi: 10.1016/S0022-1694 (03)00257-9)

Hock R, Iken A and Wangler A (1999) Tracer experiments and borehole observations in the overdeepening of Aletschgletscher, Switzerland. Ann. Glaciol., 28, 253-260 (doi: 10.3189/172756499781821742)

Huss $M$ and Fischer $M(2016)$ Sensitivity of very small glaciers in the Swiss Alps to future climate change. Front. Earth Sci., 4, 1-17 (doi: 10.3389/feart.2016.00034)

Huss $M$ and Hock R (2015) A new model for global glacier change and sea-level rise. Front. Earth Sci., 3, 1-22 (doi: 10.3389/ feart.2015.00054)

Huss M and Hock R (2018) Global-scale hydrological response to future glacier mass loss. Nat. Clim. Chang. 8, 135-140 (doi: 10.1038/s41558-017-0049-x)

Huss M, Bauder A, Funk M and Hock R (2008) Determination of the seasonal mass balance of four alpine glaciers since 1865. J. Geophys. Res., 113, F01015 (doi: 10.1029/2007JF000803)

Huss M, Dhulst L and Bauder A (2015) New long-term mass-balance series for the Swiss Alps. J. Glaciol., 61(227), 551-562 (doi: 10.3189/2015JoG15J015)

Jouvet G, Huss M, Blatter H, Picasso M and Rappaz J (2009) Numerical simulation of Rhonegletscher from 1874 to 2100 . J. Comput. Phys., 228(17), 6426-6439 (doi: 10.1016/j.jcp.2009.05.033)

Kääb A and 18 others (2018) Massive collapse of two glaciers in western Tibet in 2016 after surge-like instability. Nat. Geosci., 11, 114-120. (doi: 10.1038/s41561-017-0039-7)

Klok EJ and Oerlemans J (2002) Model study of the spatial distribution of the energy and mass balance of Morteratschgletscher, Switzerland. J. Glaciol., 48(163), 505-518 (doi: 10.3189/ 172756502781831133)

Klok EJ and Oerlemans J (2004) Modelled climate sensitivity of the mass balance of Morteratschgletscher and its dependence on albedo parameterization. Int. J. Climatol., 24(2), 231-245 (doi: 10.1002/joc.994)

Kuhn M (1984) Mass budget imbalances as criterion for a climatic classification of glaciers. Geogr. Ann. Ser. A Phys. Geogr., 66 (3), 229-238

Lefauconnier B and Hagen JO (1990) Glaciers and climate in Svalbard: statistical analysis and reconstruction of the Broggerbreen mass balance for the last 77 years. Ann. Glaciol., 14, 148-152

Lefauconnier B, Hagen JO, Ørbæk JB, Melvold $\mathrm{K}$ and Isaksson E (1999) Glacier balance trends in the Kongsfjorden area, western
Spitsbergen, Svalbard, in relation to the climate. Polar Res., 18 (2), 307-313 (doi: 10.1111/j.1751-8369.1999.tb00308.x)

Legendre P and Legendre L (2012) Numerical ecology, 3rd edn. Elsevier, Amsterdam

Letréguilly A (1988) Relation between the mass balance of western Canadian mountain glaciers and meteorological data. J. Glaciol., 34(116), 11-18

Letréguilly A and Reynaud L (1989) Spatial patterns of mass-balance fluctuations of North American glaciers. J. Glaciol., 35(120), 163-168

Lliboutry L (1974) Multivariate statistical analysis of glacier annual balances. J. Glaciol., 13(69), 371-392

Machguth H, Paul F, Kotlarski S and Hoelzle M (2009) Calculating distributed glacier mass balance for the Swiss Alps from regional climate model output: a methodical description and interpretation of the results. J. Geophys. Res. Atmos., 114(19), 1-19 (doi: 10.1029/2009JDO11775)

Martin S (1978) Analyse et reconstitution de la série des bilans annuels du Glacier de Sarennes, sa relation avec les fluctuations du niveau de trois glaciers du Massif du Mont-Blance (Bossons, Argentière, Mer de Glace). Z. Gletscherkd. Glazialgeol., 13, 127-153

Marzeion B and 5 others (2017) Observation-based estimates of global glacier mass change and its contribution to sea-level change. Surv. Geophys., 38, 105-130 (doi: 10.1007/s10712-016-9394-y)

Meier MF and Tangborn WV (1965) Net budget of flow of South Cascade Glacier, Washington. J. Glaciol., 5(41), 547-566

Nemec J, Huybrechts P, Rybak O and Oerlemans J (2009) Reconstruction of the surface mass balance of Vadret da Morteratsch, Switzerland, since 1865. Ann. Glaciol., 50, 126-134 (doi: 10.3189/172756409787769609)

Oerlemans J (2001) Glaciers and climate change. A. A. Balkema, Dordrecht

Oerlemans J and Klok EJ (2004) Effects of summer snowfall on glacier mass balance. Ann. Glaciol., 38(September 2001), 97-100

Oerlemans J and Reichert BK (2000) Relating glacier mass balance to meteorological data by using a seasonal sensitivity characteristic. J. Glaciol., 46(152), 1-6 (doi: 10.3189/172756500781833269)

Oerlemans J, Giesen RH and van Den Broeke MR (2009) Retreating alpine glaciers: increased melt rates due to accumulation of dust (Vadret da Morteratsch, Switzerland). J. Glaciol., 55(192), 729_ 736 (doi: 10.3189/002214309789470969)

Ragettli S, Immerzeel WW and Pellicciotti F (2016) Contrasting climate change impact on river flows from high-altitude catchments in the Himalayan and Andes mountains. Proc. Natl. Acad. Sci. USA, 113(33), 9222-9227 (doi: 10.1073/ pnas.1606526113)

Rasmussen LA (2004) Altitude variation of glacier mass balance in Scandinavia. Geophys. Res. Lett., 31, L13401 (doi: 10.1029/ 2004GL020273)

Reeh N (1989) Parameterization of melt rate and surface temperature on the Greenland ice sheet. Polarforschung, 593, 113-128

Rossini $\mathrm{M}$ and 7 others (2018) Rapid melting dynamics of an alpine glacier with repeated UAV photogrammetry. Geomorphology, 304, 159-172 (doi: 10.1016/j.geomorph.2017.12.039)

Réveillet M, Vincent C, Six D and Rabatel A (2017) Which empirical model is best suited to simulate glacier mass balances? J. Glaciol., 63(237), 39-54 (doi: 10.1017/jog.2016.110)

Sicart JE, Hock R and Six D (2008) Glacier melt, air temperature, and energy balance in different climates: the Bolivian tropics, the French Alps, and northern Sweden. J. Geophys. Res., 113, D24113 (doi: 10.1029/2008JD010406)

Sodemann H, Palmer AS, Schwierz C, Schwikowski M and Wernli H (2006) The transport history of two Saharan dust events archived in an alpine ice core. Atmos. Chem. Phys., 6, 667-688 (doi: 10.5194/acpd-5-7497-2005)

Sold L and 8 others (2016) Mass balance re-analysis of Findelengletscher, Switzerland; benefits of extensive snow accumulation measurements. Front. Earth Sci., 4(February), 1-16 (doi: 10.3389/feart.2016.00018) 
Tangborn WV (1980) Two models for estimating climate-glacier relationships in the North cascades, Washington, USA. J. Glaciol., 25(91), 3-21

Thibert E, Eckert N and Vincent C (2013) Climatic drivers of seasonal glacier mass balances: an analysis of 6 decades at Glacier de Sarennes (French Alps). Cryosphere, 7, 47-66 (doi: 10.5194/tc7-47-2013)

Tinsley HEA and Brown SD (2000) Handbook of applied multivariate statistics and mathematical modeling. Academic Press, San Diego, CA

Torinesi O, Letréguilly A and Valla F (2002) A century reconstruction of the mass balance of Glacier de Sarennes, French Alps. J. Glaciol., 48 (160), 142-148 (doi: 10.3189/172756502781831584)

Trachsel M and Nesje A (2015) Modelling annual mass balances of eight Scandinavian glaciers using statistical models. Cryosphere, 9(4), 1401-1414 (doi: 10.5194/tc-9-1401-2015)

Vaughan D and 13 others (2013) Observations: cryosphere. Stocker TF and 9 others eds. Climate change 2013: the physical science basis. Contribution of Working Group I to the Fifth Assessment Report of the Intergovernmental Panel on Climate Change. Cambridge University Press, Cambridge, UK, 317-382 (doi: 10.1017/CBO9781107415324.012)

Vincent $C$ and 5 others (2012) Detection of a subglacial lake in Glacier de Tête Rousse (Mont Blanc area, France). J. Glaciol., 58(211), 866-878 (doi: 10.3189/2012JoG11J179)

Vincent $C$ and 9 others (2017) Common climatic signal from glaciers in the European Alps over the last 50 years. Geophys. Res. Lett., 44, 1376-1383 (doi: 10.1002/2016GL072094)

Vincent C and Vallon M (1997) Meteorological controls on glacier mass balance: empirical relations suggested by measurements on glacier de Sarennes, France. J. Glaciol., 43(143), 131-137
Werder MA, Bauder A, Funk M and Keusen HR (2010) Hazard assessment investigations in connection with the formation of a lake on the tongue of Unterer Grindelwaldgletscher, Bernese Alps, Switzerland. Nat. Hazards Earth Syst. Sci., 10(2), 227237 (doi: 10.5194/nhess-10-227-2010)

Whittingham MJ, Stephens PA, Richard B and Freckleton RP (2006) Why do we still use stepwise modelling in ecology and behaviour? J. Anim. Ecol., 75, 1182-1189 (doi: 10.1111/j.1365-2656.2006. 01141.x)

Young GJ (1977) Relations between mass-balance and meteorological variables. Z. Gletscherkd. Glazialgeol., 13(1/2), $111-125$

Zekollari H (2017) TopoZeko: a MATLAB function for 3-D and 4-D topographical visualization in geosciences. SoftwareX, 6, 285292 (doi: 10.1016/j.softx.2017.10.004)

Zekollari H and Huybrechts P (2015) On the climate-geometry imbalance, response time and volume-area scaling of an alpine glacier: insights from a 3-D flow model applied to Vadret da Morteratsch, Switzerland. Ann. Glaciol., 56(70), 51-62 (doi: 10.3189/2015AoG70A921)

Zekollari H, Huybrechts P, Fürst JJ, Rybak O and Eisen O (2013) Calibration of a higher-order 3-D ice-flow model of the Morteratsch glacier complex, Engadin, Switzerland. Ann. Glaciol., 54(63), 343-351 (doi: 10.3189/2013AoG63A434)

Zekollari H, Fürst JJ and Huybrechts P (2014) Modelling the evolution of Vadret da Morteratsch, Switzerland, since the little Ice Age and into the future. J. Glaciol., 60(224), 1208-1220 (doi: 10.3189/2014JoG14J053)

Zemp M and 38 others (2015) Historically unprecedented global glacier decline in the early 21 st century. J. Glaciol., 61(228), 745-762 (doi: 10.3189/2015JoG15J017)

MS received 5 February 2017 and accepted in revised form 7 February 2018; first published online 22 March 2018 